\title{
Energy Auditing: A Walk through Survey of Library Building of Institute to Reduce the Lighting Cost
}

\author{
S. B. Halbhavi ${ }^{1}$, Vani P. Datar ${ }^{1}$, S. G. Kulkarni ${ }^{1}$, Shambhavi Patil ${ }^{1}$, Pallavi S. Terani ${ }^{1}$ \\ Dept of Electrical \& Electronics Engineering, Gogte Institute of Technology, Belgaum Karnataka, India ${ }^{1}$
}

\begin{abstract}
This paper presents simple walk though energy audit for the lighting load of library section of educational institution. Lighting is a major load in case of educational institution particularly in library section. Lighting is an area which provides a major scope for achieving energy efficiency at the design stage by using the modern energy efficient lamps. Innovation and continuous improvements in lighting design has given big energy saving options. Implementation of energy audit can reduce the wastage of energy and gives good practice of energy conservation. In this paper library loads have been surveyed tabulate, energy saving measures is analyzed involves the replacement of low efficient lighting by high efficient lighting. The outcome of evaluation namely annual consumption reduction, greenhouse gas reduction and payback period is presented.
\end{abstract}

Key words: Energy audit, lighting, payback period, energy conservation.

\section{INTRODUCTION}

In modern era day to day activities of human being is A successful energy management program begins with depends on electricity. Conservation of electrical energy is energy conservation; it will lead to adequate rating of the need of the hour. Electricity demand is increasing day equipments, using high efficiency equipments and change by day. India ranks fourth in the world in total installed of habits which cause enormous wastage of energy $[5,6]$. power capacity [1]. All India installed capacity in MW of power stations is 272687.17 as on April 2015 [2]. The detailed break up share of different types of generating stations is mentioned below-

Thermal power plant - 189497.78MW, Hydro power plant - 41632.43MW, Nuclear power plant - 5780.00MW and Renewable energy sources - 35776.96MW; Total 272687.17MW [2].

The electric energy generation is a measure of economical progress of the country and the economical development of the country depends on per capita consumption of energy. Table1. Shows the per capita consumption of different countries; all economically developed countries per capita consumption of electrical energy is high. Even though India ranks fourth in the world for power generation, because of population per capita consumption of energy is less. Graph shown in figure 1, indicates the growth of per capita consumption of India from year 200506 to 2013-14, it has increased from 631.4kWH to $957 \mathrm{kWH}$ [3]. At present only $78.7 \%$ of Indian population is access to electricity [7]. To become developed country per capita consumption of energy needs to be increased, this requires increasing the generation capacity. To establish the new power plants to increase the power supply needs more time.

India is facing over 25000-30000 MW, power shortage daily due to breakdown, repair and maintenance work of the power plant [4]. Until generation over comes this shortage of power supply, India needs to focus on energy conservation. Energy conservation means reduction in energy consumption without making sacrifice of quantity or quality.

\begin{tabular}{|c|c|}
\hline \multicolumn{2}{|c|}{$\begin{array}{c}\text { Table.1; Per Capita Consumption of } \\
\text { Developed Countries }\end{array}$} \\
\hline Country & Kwh \\
\hline United Arab Emirates & $15,131.10$ \\
\hline United States & $12,185.94$ \\
\hline Australia & $9,485.68$ \\
\hline Switzerland & $7,315.01$ \\
\hline Russia & $7,285.73$ \\
\hline Germany & $7,191.65$ \\
\hline France & $6,986.22$ \\
\hline Saudi Arabia & $6,980.92$ \\
\hline Japan & $6,763.79$ \\
\hline European Union & $5,938.20$ \\
\hline China & $3,925.67$ \\
\hline Brazil & $2,249.12$ \\
\hline India & 957.00 \\
\hline World & $2,850.33$ \\
\hline
\end{tabular}

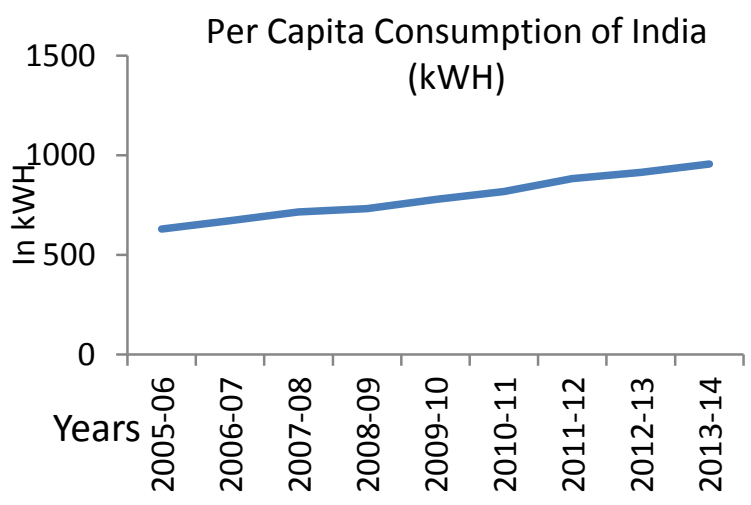

Figure 1; Per Capita Consumption of India 


\section{ENERGY CONSERVATION AND AUDIT}

As per the Energy Conservation Act 2001, Energy Audit is defined as "the verification, monitoring and analysis of use of energy including submission of technical report containing recommendations for improving energy efficiency with cost benefit analysis and an action plan to reduce energy consumption". Implementation of recommended measures can help to achieve significant reduction in the energy consumption levels [8]. Studies and survey have shown $35-40 \%$ of the load in big cities is lighting load.CFL, LED and electronic ballast in tube light will save $25-30 \%$ of power with estimated 673.3 million tube lights in India by the year 2016, a saving of 15 watts per tube light will mean $1000 \mathrm{MW}$ of load and saving of 45 million units a day @ 4hours of usages a day [9].

\section{TYPES OF ENERGY AUDIT}

The term energy audit is commonly used to describe a broad spectrum of energy studies ranging from a quick walk-through of a facility to identify major problem areas to a comprehensive analysis of the implications of alternative energy efficiency measures sufficient to satisfy the financial criteria of investors.

- Benchmarking: Benchmarking mainly consists of comparing the measured consumption with reference consumption of other similar loads or generated by simulation tools to identify excessive or unacceptable running costs.

- Walk-through audit: The preliminary audit (alternatively called a simple audit, screening audit or walk-through audit) is the simplest and quickest type of audit. It involves minimal interviews with siteoperating personnel, a brief review of facility utility bills and other operating data, and a walk-through of the facility to become familiar with the operation and to identify any glaring areas of energy waste or inefficiency.

- Detailed/General energy audit: The general audit (alternatively called a mini-audit, site energy audit or detailed energy audit or complete site energy audit) expands on the preliminary audit described above by collecting more detailed information about facility operation and by performing a more detailed evaluation of energy conservation measures. This level of analysis can involve advanced on-site measurements and sophisticated computer based simulation tools to evaluate precisely the selected energy retrofits.

- Investment-Grade audit: In most corporate settings, upgrades to a facility's energy infrastructure must compete for capital funding with non-energy-related investments. Both energy and non-energy investments are rated on a single set of financial criteria that enerally stress the expected return on investment $[10$, $11]$.

\section{ENERGY SAVINGS ON LIGHTING SYSTEM}

Possibility of energy conservation is more in educational building due to the fact that huge numbers of people are involved. Lighting load is where most of the energy is wasted than consumption. In library building lighting load consumes more than $40 \%$ of the total electrical energy consumption. Remaining loads are fans, computers, water cooler and air conditioner. In walk through survey it is observed that most of fluorescence tubes light of 36 Watts are having choke coil/ electronic ballast, these needs to be replaced by LED tube light of 18 Watt capacity. Following table 2 gives comparison between Fluorescence tube light and LED T8 tube light and reason for replacement [12, 13].

Lamp selection must be based on several factors, such us: efficiency (ratio between light output and electric power input -lumens per watt), color temperature, color rendering index, life and lumen maintenance, availability and cost [14]. Lives of different luminaries are shown in the figure 2 [15]. It is observed that life of LED tube light is more than fluorescent tube and power consumption is also less for same lumen output.

The objective of this paper is to study the energy consumption due to lighting loads in a library building of the KLS Gogte Institute of Technology, Belgaum, India and reduce the consumption without affecting the outputs. The institute library building is considered here because of the uncontrolled and unpredictable usage of light in different sections. An audit activity in general order includes:

- Identification of all types of lighting loads.

- Evaluation of the condition of the systems.

- Analysis of impact of improvement to those systems.

- Preparation of energy audit report.

Economical analysis is done after energy audit work using all the data gathered.

Following table 3 gives the details of the walk through survey to identify the number of fluorescent tube lights in different section of library building of Gogte Institute of Technology, Belgaum, India. A count of lighting is done after proper identification and calculation about the replacement of the light as it should not affect consumers need. Even though library section is open for the students $24 \times 7$ but actual hours of usage in different section are mentioned in the table. Energy calculation is made assuming 30 days in the month. Gogte Institute of Technology is having HT connection from Hubli Electricity Supply Company for its electrical energy supply, a tariff of Rs. 8.00 as per electricity bill / month is considered for the calculation of the yearly energy consumption bill. 
Table 2: Comparison between Fluorescent Tube-light and LED

\begin{tabular}{|c|c|}
\hline Fluorescence tube-light & LED T8 tube-light \\
\hline $\begin{array}{l}\text { Fluorescent Tube light is a gas discharge lamp, which } \\
\text { contains gases like Mercury. It produces short wave ultraviolet } \\
\text { light that gets transformed into visible light, the inside of the tube } \\
\text { has a phosphor lining (coating). }\end{array}$ & $\begin{array}{l}\text { Light Emitting Diode (LED) is a semiconductor } \\
\text { diode. In forward biased condition the electrons recombine with } \\
\text { holes, and then it release some energy in the form of photon } \\
\text { (visible light). }\end{array}$ \\
\hline $\begin{array}{l}\text { - More amount of electrical energy converted into heat } \\
\text { and small amount is converted into light compared to LED tube } \\
\text { light. }\end{array}$ & $\begin{array}{l}\text { The electrical energy is converted into } 80 \% \text { light } \\
\text { energy; remaining } 20 \% \text { get converted into heat energy. }\end{array}$ \\
\hline Harmful chemical (like mercury) are used. & No harmful chemical used \\
\hline $\begin{array}{l}\text { - } 36 \text { watts fluorescent lamp, light output is } 2000 \text { lumens, } \\
\text { so system efficacy is } 55 \mathrm{~lm} / \text { watt. Rated life is } 5,000 \mathrm{hrs} \text {. Tube } \\
\text { light efficiency comes down with time. }\end{array}$ & $\begin{array}{l}\text { Power consumption is } 18 \text { watts, System Efficacy } 123 \\
\text { lumens/watt, so total light output (Luminous Flux) is } 2000 \\
\text { lumens. Life span ( } 50,000 \text { hours) is very high for led lights over } \\
\text { other lights. }\end{array}$ \\
\hline $\begin{array}{l}\text { - Fluorescent lights it runs using electronic ballast (called } \\
\text { solid state ballast) which consume above } 12 \text { watts power. } \\
\text { Dimming is not available for this ballast. }\end{array}$ & $\begin{array}{l}\text { Power consumption is very low. And no need to use } \\
\text { electronic ballast because it runs by constant current and voltage. } \\
\text { Dimming also available for the LED lights. }\end{array}$ \\
\hline $\begin{array}{l}\text { - Beam Angle is very important in every lighting } \\
\text { technology. For Fluorescent lamp Beam angle is } 360 \text { degree. We } \\
\text { can calculate the beam spread only for } 270 \text { degree, } 90 \text { degree beam } \\
\text { angle is wasted }\end{array}$ & $\begin{array}{l}\text { - Led lights are available with variety of Beam Angle, } \\
\text { Beam Angle is } 120 \text { degree for our LED Tube Light, we can } \\
\text { calculate beam spread for } 120 \text { degree }\end{array}$ \\
\hline Beam Spread $=48.6($ Recommended height is $10 \mathrm{ft})$ & Beam Spread $=21.6($ Recommended height is $10 \mathrm{ft})$ \\
\hline $\begin{array}{l}\text { - It will emit the yellowish white color. It has a low Color } \\
\text { temperature and Color Rendering Index (Color Tempreature-4100 } \\
\text { Kelvin, CRI-80) }\end{array}$ & $\begin{array}{l}\text { - It can emit the cool white color in the spectrum of } \\
380-740 \mathrm{~nm} \text {. For Humans also the visible spectrum is } 380-740 \\
\mathrm{~nm} \text {. }\end{array}$ \\
\hline
\end{tabular}

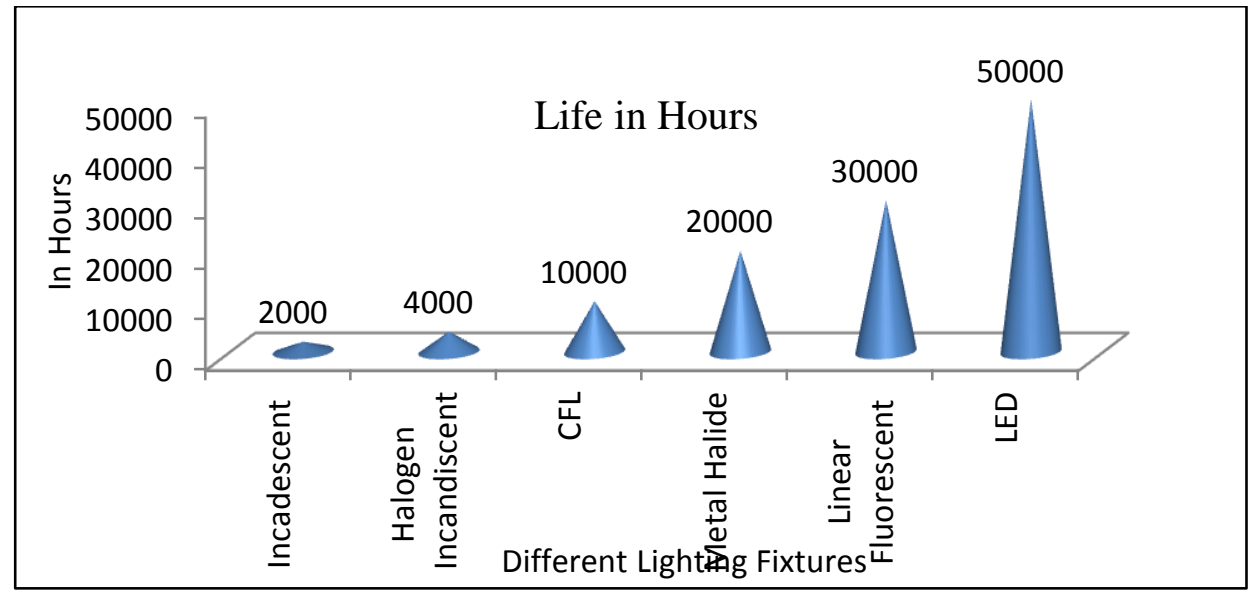

Figure 2; Comparison of life of different lighting fixtures

\begin{tabular}{|c|c|c|c|c|c|c|c|}
\hline Venue detail & $\begin{array}{c}\text { No. of } \\
\text { tubes }\end{array}$ & $\begin{array}{c}\text { Wattage } \\
\text { of tube } \\
\text { light }\end{array}$ & $\begin{array}{l}\text { Hours } \\
\text { of } \\
\text { usage }\end{array}$ & $\begin{array}{c}\text { Energy } \\
\text { Consumption } \\
\text { per day } \\
\text { in kWH }\end{array}$ & $\begin{array}{l}\text { Energy } \\
\text { Consumption } \\
\text { per Month } \\
\text { in kWH }\end{array}$ & $\begin{array}{c}\text { Energy } \\
\text { Consumption } \\
\text { per year } \\
\text { in kWH }\end{array}$ & $\begin{array}{c}\text { Electricity Bill } \\
\text { paid per year@ } \\
\text { Rs. 8/- in Rs. }\end{array}$ \\
\hline Reading Hall no. & 27 & 36 & 15 & 14.58 & 437.4 & 5248.8 & $41,990.40$ \\
\hline Entrance lobby & 21 & 36 & 12 & 9.072 & 272.16 & 3265.92 & $26,127.36$ \\
\hline Librarian Room & 4 & 36 & 7 & 1.008 & 30.24 & 362.88 & $2,903.04$ \\
\hline A-Partition & 7 & 36 & 14 & 3.528 & 105.84 & 1270.08 & $10,160.64$ \\
\hline $\begin{array}{c}\text { PG Section n stack } \\
\text { room }\end{array}$ & 17 & 36 & 4 & 2.448 & 73.44 & 881.28 & $7,050.24$ \\
\hline Stock room & 24 & 36 & 5 & 4.32 & 129.6 & 1555.2 & $12,441.60$ \\
\hline Sore room & 3 & 36 & 4 & 0.432 & 12.96 & 155.52 & $1,244.16$ \\
\hline Reference section & 12 & 36 & 4 & 1.728 & 51.84 & 622.08 & $4,976.64$ \\
\hline Journal section & 12 & 36 & 4 & 1.728 & 51.84 & 622.08 & $4,976.64$ \\
\hline \multirow[t]{2}{*}{ Digital library } & 6 & 36 & 10 & 2.16 & 64.8 & 777.6 & $6,220.80$ \\
\hline & 133 & & & & & 14761.44 & $118,091.52$ \\
\hline
\end{tabular}

Table 3; Walk-through Survey Details of Existing Lighting Fixtures 
INTERNATIONAL JOURNAL OF INNOVATIVE RESEARCH IN ELECTRICAL, ELECTRONICS, INSTRUMENTATION AND CONTROL ENGINEERING Vol. 3, Issue 8, August 2015

\begin{tabular}{|c|c|c|c|c|c|c|c|}
\hline Venue detail & $\begin{array}{l}\text { No. of } \\
\text { LED T8 } \\
\text { tubes }\end{array}$ & $\begin{array}{l}\text { Wattage } \\
\text { of LED } \\
\text { tube light }\end{array}$ & $\begin{array}{c}\text { Hours } \\
\text { of } \\
\text { usage }\end{array}$ & $\begin{array}{c}\text { Energy } \\
\text { Consumption } \\
\text { per day } \\
\text { in } \mathrm{kWH}\end{array}$ & $\begin{array}{l}\text { Energy } \\
\text { Consumption } \\
\text { per Month } \\
\text { in kWH }\end{array}$ & $\begin{array}{c}\text { Energy } \\
\text { Consumption } \\
\text { per year } \\
\text { in kWH }\end{array}$ & $\begin{array}{c}\text { Electricity Bill } \\
\text { paid per year@ } \\
\text { Rs. 8/- in Rs. }\end{array}$ \\
\hline Reading Hall no. & 27 & 18 & 15 & 7.29 & 218.7 & 2624.4 & $20,995.20$ \\
\hline Entrance lobby & 21 & 18 & 12 & 4.536 & 136.08 & 1632.96 & $13,063.68$ \\
\hline Librarian Room & 4 & 18 & 7 & 0.504 & 15.12 & 181.44 & $1,451.52$ \\
\hline A-Partition & 7 & 18 & 14 & 1.764 & 52.92 & 635.04 & $5,080.32$ \\
\hline $\begin{array}{c}\text { PG Section n stack } \\
\text { room }\end{array}$ & 17 & 18 & 4 & 1.224 & 36.72 & 440.64 & $3,525.12$ \\
\hline Stock room & 24 & 18 & 5 & 2.16 & 64.8 & 777.6 & $6,220.80$ \\
\hline Sore room & 3 & 18 & 4 & 0.216 & 6.48 & 77.76 & 622.08 \\
\hline Reference section & 12 & 18 & 4 & 0.864 & 25.92 & 311.04 & $2,488.32$ \\
\hline Journal section & 12 & 18 & 4 & 0.864 & 25.92 & 311.04 & $2,488.32$ \\
\hline \multirow[t]{2}{*}{ Digital library } & 6 & 18 & 10 & 1.08 & 32.4 & 388.8 & $3,110.40$ \\
\hline & 133 & & & & & 7380.72 & $59,045.76$ \\
\hline
\end{tabular}

Table 4; Proposed LED Lighting Scheme with Tariff Calculation for Year

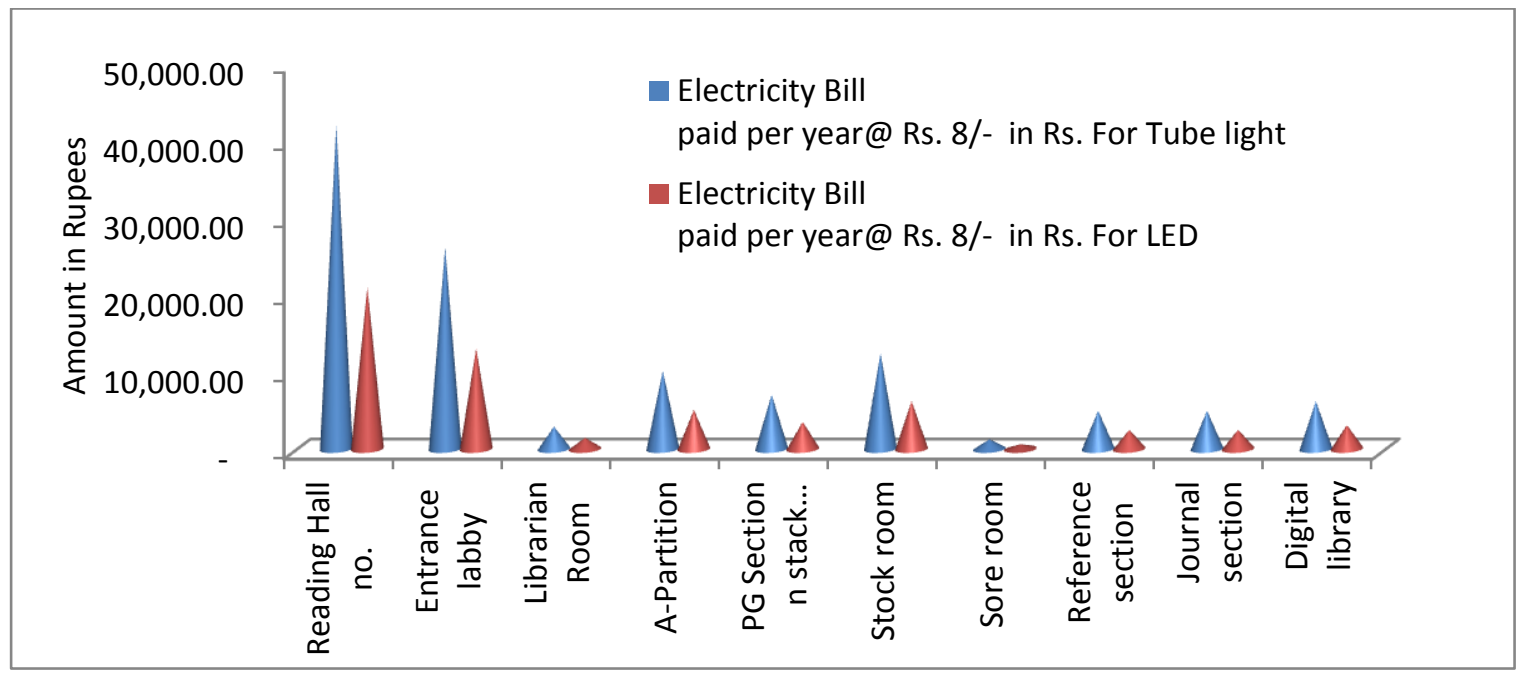

Figure 3; Tariff Wise Comparison

Fluorescent tubes in the different sections of the library are replaced by the T8 LED tube of 18 watts, then energy consumption and tariff per year at the rate of Rs. 8.00 is shown in the table 4. Figure 3 shows the comparison of tariffs before and after replacement of fluorescent tube lights with LED tube lights.

The initial investment in replacing the existing fluorescent tube lights with LED tube lights at the rate of Rs. 900.00 per tube (Approximate competitive price assumed) is 133 x $900=$ Rs. 119700.00 . Net saving in the electricity bill per year is Rs. 118,091.52 - Rs.59, 045.76 = Rs. 59,045.76. Payback period for investment is $119700.00 / 59045.76=$ 2.02 years. This implies that the break even occurs at 2.02 years and LED tube lights start to payback after 2.02 years.

\section{RECOMMENDATIONS}

- As initial investment cost for LED tube light is more, fluorescent tube lights can be replaced with LED tube lights in a phase manner (can be replaced one by one when tube light gets damaged).

- Consider purchasing of ENERGY STAR-qualified fixtures. They are available in many styles; distribute light more efficiently and evenly than standard fixtures, and some offer convenient features such as dimming.

- Keep curtains or shades open to use day lighting instead of turning on lights. Also, decorate with lighter colors that reflect daylight.

- Practice of turning off the light when not required.

- Better arrangement for the day light can be made. $\mathrm{CO}_{2}$ emission is reduced when tube lights are replaced. Every kWH of energy saved, $0.9389 \mathrm{Kg}$ of carbon dioxide emission is reduced. In above case units saved per year is $7380 \mathrm{kWH}$ (approx), this is equals to $6922 \mathrm{Kg}$ of reduction of $\mathrm{CO} 2$ emission to atmosphere every year [16]. 


\section{CONCLUSION}

The above discussion shows that replacement of fluorescent tube lights with LED T8 tube lights will reduce the energy consumption drastically. Saving energy will help reduce carbon footprint on earth and help green cover of our planet. Detailed study of illumination level required in different sections of library considering day light usage will further reduces the number of luminaries with proper wiring design.

Energy audit in all the sectors with few or moderate changes in existing system will reduce the power demand of the country. The government can decide strict polices to initiate energy audit in domestic and institute sectors where the lighting load is major one. This will make great change in economical status.

\section{ACKNOWLEDGEMENT}

The authors would like to thank all the assistance and support received from library and department of Electrical Engineering of Gogte Institute of Technology, Belgaum, India.

\section{REFERENCES}

[1]. List of countries by electricity production (Online) 2014. Available; https://en.wikipedia.org/wiki/List_of_countries_by_electricity_prod uction 2014

[2]. All India installed capacity (in mw) of power stations -revised report as on April 2014 of Ministry of Power Central Electricity Authority (Online). Available; http://www.cea.nic.in/installed_capacity.html

[3]. Per capita consumption of electricity " Government of India Ministry of Power Central Electricity Authority, New Delhi” executive summary power sector January 2015.

[4]. Power shortage in India- news letter (Online). Available; http://www.livemint.com/Industry/tnV2NUSAK8PbFs7pSzoL0I/In dia-faces-daily-power-outage-of-30000-MW.html

[5]. Malkiat Singh, Gurupreet Singh, Harmandeep Singh; "Energy audit: A case study to reduce lighting cost", Asian Journal of Computer Science and Information Technology 2: 5(2012) 119122, ISSN 2249-5126.

[6]. Guide book from Bureau of Energy Efficiency; "General Aspect of Energy Management and Energy Audit" chapter no. 3, http://beeindia.in/energy_managers_auditors/documents/guide_boo ks/1Ch3.pdf

[7]. Access to electricity(\% population wise),database from World Bank, Global Electrification database (Online) available; http://data.worldbank.org/indicator/EG.ELC.ACCS.ZS

[8]. IQMS Consultancy Services Private Limited a professionally managed company; "Auditing and Calibration" (Online) Available; http://www.iqmsindia.com/auditing-training.html.

[9]. The world bank report -Background Paper India: "Strategies for Low Carbon Growth" draft copy July 2008 (online). Available; http://www.moef.nic.in/downloads/public information/Residentialpowerconsumption.pdf

[10]. Ramya L. N. and M. A. Femina " Energy Auditing-A walk through Survey" International Journal of Advance Research in Electrical, Electronic and Instrumentation Engineering, Vol.3, Special issue 2, April 2014, ISSN (Online) 2278-8875.

[11]. Energy Audit-“Type of Energy Audit"- (Online) Available; https://en.wikipedia.org/wiki/Energy_audit

[12]. LED vs Fluorescent: 10 Problems To Consider With Fluorescent Lighting (On line). Available; http://www.hoveyelectric.com/hovey-electric-powerblog/bid/100379/

[13]. NaBa Green Energy - LED tube light vs fluorescent tube light (On line) Available; http://nabagreen.blogspot.in/2010/09/led-tubelight-vs-fluorescent-tube.html

[14]. J. Lemos, D. Coelho, and M. Valdez, "Efficient Lighting in a Portuguese School Technology Tondela's Professional School" published in IEEE conference- Energetics (IYCE), Proceedings of the 2011 3rd International Youth Conference, 7-9 July 2011, page 1-7, ISBN 978-1-4577-1494-8.

15]. Life of white LED - PNNL-SA-50957 September 2009 (Online). Available;

http://apps1.eere.energy.gov/buildings/publications/pdfs/ss1/lifetime white_leds.pdf

[16]. U.S. Energy Information and Administration-“CO2 production per Kwh consumption of energy" frequently asked question section (online).

http://www.eia.gov/tools/faqs/faq.cfm?id=74\&t=11,

http://nabagreen.blogspot.in/2011/05/carbon-footprint.html

\section{BIOGRAPHIES}

Mr. S. B. Halbhavi, obtained Bachelor of Electrical Engineering degree from Basaveswar Engineering College, Bagalkot, affiliated to Karnataka University Dharwad, India in the year 1984, and master degree in Electronics and control from Birla Institute of Technology, Pilani, Rajasthan, in the year 1996, perusing research work in the field of distributed power system. At present he is working as Associated Professor in the department of Electrical \& Electronics Engineering of Gogte Institute of Technology, Belgaum, India.

Mrs. Vani P. Datar, obtained Bachelor of Electrical Engineering degree from KLS, Gogte Institute of Technology, Belgaum, India, affiliated to Visvesvaraya Technological University, Belgaum, Karnataka, in the year 2003, and Master degree in Digital Electronics from Visvesvaraya Technological University, Belgaum, Karnataka in the year 2009. At present she is working as Assistant Professor in the department of Electrical \& Electronics Engineering of Gogte Institute of Technology, Belgaum, India.

Mr. S. G. Kulkarni, obtained Bachelor of Electrical Engineering degree from BVB College of Engineering Hubli, affiliated to Karnataka University Dharwad, Karnataka in the year 1986, and Master degree in Electronics and control from Birla Institute of Technology, Pilani, Rajasthan, in the year 1996, Masters degree in Digital Electronics from Gogte Institute of Technology, Belgaum, Karnataka, affiliated to Visvesvaraya Technological University, Belgaum Karnataka, in the year 2011. At present he is working as Associated Professor and head of the department of Electrical \& Electronics Engineering of Gogte Institute of Technology, Belgaum, India.

Miss Shambhavi Patil and Pallavi S. Terani, are final year students in Electrical \& Electronics Engineering Department of Gogte Institute of Technology, Belgaum, India. Presently they are carrying out the project work in the field of Energy Auditing and Energy Management of College building. 